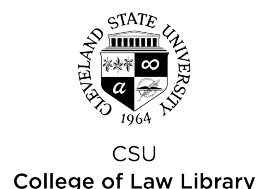

Cleveland State University

College of Law Library

\title{
EngagedScholarship@CSU
}

\section{Information Warfare: The Legal Aspects of Using Satellites and Jamming Technologies in Propaganda Battles}

\author{
Mark J. Sundahl \\ Cleveland-Marshall College of Law, Cleveland State University, m.sundahl@csuohio.edu
}

Follow this and additional works at: https://engagedscholarship.csuohio.edu/fac_book_contributions

Part of the Air and Space Law Commons, Communication Technology and New Media Commons, and the Military, War, and Peace Commons

How does access to this work benefit you? Let us know!

\section{Repository Citation}

Sundahl, Mark J., "Information Warfare: The Legal Aspects of Using Satellites and Jamming Technologies in Propaganda Battles" (2006). Law Faculty Contributions to Books. 270.

https://engagedscholarship.csuohio.edu/fac_book_contributions/270

This Article is brought to you for free and open access by the Faculty Scholarship at EngagedScholarship@CSU. It has been accepted for inclusion in Law Faculty Contributions to Books by an authorized administrator of EngagedScholarship@CSU. For more information, please contact research.services@law.csuohio.edu. 


\title{
IAC-06-E6.4.12
}

\section{INFORMATION WARFARE: THE LEGAL ASPECTS OF USING SATELLITES AND JAMMING TECHNOLOGIES IN PROPAGANDA BATTLES}

\author{
Mark J. Sundahl* \\ Cleveland State University, Cleveland-Marshall College of Law \\ United States \\ mark.sundahl@law.csuohio.edu
}

\begin{abstract}
This paper examines the right of states to broadcast propaganda by satellite in times of war. In exploring this issue, the author addresses the hypothetical question of whether a state may use DBS technology to broadcast a commercial news program, such as $\mathrm{CNN}$, into an enemy state in wartime as part of a larger campaign to win the support of the civilian population. The author begins by establishing that that the consent of a receiving state is required prior to such broadcasts, whether in peacetime or in times of war. This requirement of "prior consent" is the only restriction of the broadcasting of such news programs since the programs do not rise to the level of illegal war propaganda nor would such broadcasts be prohibited by the international law demanding that outer space be used only for "peaceful purposes." This analysis concludes with the warning that the inviolability of the "prior consent" doctrine may be threatened by the recent adoption by the United States of a more relaxed theory of what measures may be taken under the right of self-defense. Finally, the author takes up the related question regarding the right of states to use jamming technologies to block illegal satellite transmissions.
\end{abstract}

\section{INTRODUCTION}

The fundamental question posed in this paper is whether a country has the right in times of war to use free-to-air direct broadcasting satellite (DBS) technology to broadcast commercial news programming, such as $\mathrm{CNN}$, into an enemy state. A state may want to undertake such broadcasts during a defensive war as part of a larger campaign to win the support of the civilian population or at least counteract misinformation promulgated on the ground. The scenario of broadcasting commercial news programs was selected for this analysis because such programming constitutes a mild form of propaganda, as opposed to the more likely illegal forms of propaganda that

\footnotetext{
* Assistant Professor, Cleveland State University, Cleveland-Marshall College of Law. The author wishes to thank Cleveland-Marshall College of Law for supporting this research. This paper benefited from the able research assistance of Daniel Thiel.
} 
incite sedition or racial hatred. The legalities of broadcasting news programs is less clear than in the case of more extreme war propaganda, and therefore raises more difficult and interesting questions.

\section{II. "PRIOR CONSENT" AND OTHER RESTRICTIONS ON BROADCASTING PROPAGANDA}

The legality of DBS broadcasts of commercial news programming hinges on the applicability of certain doctrines of international law including the "prior consent" doctrine, the prohibition of war propaganda, and the requirement that outer space be used for "peaceful purposes." As explained below, the right to broadcast commercial news is in fact limited only by the "prior consent" doctrine.

\section{A. The "Prior Consent" Doctrine}

The general rule governing television broadcasting using DBS technology is that the sending state must receive the consent of any receiving state before initiating transmission. This view is based on the fundamental principle of state sovereignty which has been broadly interpreted as granting states the right to control the flow of information across their borders. Although this rule is not recognized as settled law by all nations or scholars, evidence in the forms of international resolutions, declarations, regulations, and state practice almost certainly provides sufficient proof that customary international law requires prior consent.

The primary document supporting the "prior consent" doctrine is the United Nations General Assembly Resolution on Principles Governing the
Use by States of Artificial Earth Satellites for International Direct Television Broadcasting (Resolution 37/92). ${ }^{1}$ Paragraph 14 of Resolution $37 / 92$ provides that "an international direct television broadcasting satellite service shall only be established after the conditions set forth in Paragraph $13 \ldots$ have been met."' Paragraph 13, in turn, requires a state intending to initiate DBS broadcasting into another state to "notify the proposed receiving State or States of such intention and ... promptly enter into consultation with any of those States which so requests."3

The "prior consent" doctrine is expressed even more clearly in Article IX of the 1972 UNESCO Declaration of Guiding Principles on the Use of Satellite Broadcasting for the Free Flow of Information, the Spread of Education and Cultural Exchange which requires states to "reach or promote prior agreements concerning direct satellite broadcasting to the population of countries other than the country of origin of the transmission."4

In addition, the 1978 UNESCO Declaration on Fundamental Principles Concerning the Contribution of the Mass Media to Strengthening Peace and International Understanding to the Promotion of Human Rights and to Countering Racialism, Apartheid and Incitement to War (Mass Media

\footnotetext{
${ }^{1}$ Resolution on Principles Governing the Use by States of Artificial Earth Satellites for International Direct Television Broadcasting, G.A. Res. 37/92, U.N. Doc. A/37/646 (1982) [hereinafter, Resolution 37/92).

2 Id. para. 14.

${ }^{3}$ Id. para. 13 (emphases added).

${ }^{4}$ UNESCO Declaration of Guiding Principles on the Use of Satellite Broadcasting for the Free Flow of Information, the Spread of Education and Cultural Exchange, art. IX, U.N. Doc. A/C.1/L. 605 (1972) (emphasis added).
} 
Declaration) rejects the unlimited "free flow" approach by calling for a "wider and more balanced dissemination of information." 5 This language has been interpreted by some commentators as permitting international prohibitions on the broadcast of objectionable media. ${ }^{6}$

The regulations issued by the International Telecommunications Union (ITU) also embrace the "prior consent" doctrine by requiring states to "reduce, to the maximum extent practicable, the radiation over the territory of other countries unless an agreement has been previously reached with such countries." 7 In addition to this requirement for prior consent, the ITU regulations require that states be capable of immediately ceasing their broadcasts into other states if such states object to the transmission. ${ }^{8}$

The alternative to the "prior consent" approach is the "free flow" doctrine which asserts that a sending state need not acquire the consent of a receiving nation prior to broadcasting into that state. Proponents of the "free flow" doctrine point to certain documents which, they claim, indicate an inviolable right of peoples to send

5 UNESCO Declaration on Fundamental Principles Concerning the Contribution of the Mass Media to Strengthening Peace and International Understanding to the Promotion of Human Rights and to Countering Racialism, Apartheid and Incitement to War, art. IX, UNESCO Gen. Conf. Res. 4/9.3/2, 20th Sess. (1978), reprinted in ANN. REV. U.N. AFF. 23840 [hereinafter, Mass Media Declaration].

6 See, e.g., Joel R. Paul, Images from Abroad: Making Direct Broadcasting by Satellites Safe for Sovereignty, 9 HASTINGS INT'L \& COMP. L. R. 329, 340 (1986).

${ }^{7}$ Final Acts of the World Administrative Radio Conference for Space Telecommunications, ITU, Radio Regulations No. 2674 (1971), 23 U.S.T. 1527, T.I.A.S. No. 7435 (1971).

8 Id. No. 470V. and receive information, whether by satellite broadcasts or other means. Proponents of the "free flow" doctrine rely primarily on Article 19 of the Universal Declaration of Human Rights which provides that all people have the right "to seek, receive, and impart information and ideas through any media and regardless of frontiers." 9 Article 19 of the International Covenant on Civil and Political Rights (ICCPR) contains virtually identical language asserting the right of all people to send and receive information across borders. ${ }^{10}$

Although the language of the Declaration of Human Rights and the ICCPR celebrating the fundamental right to information appears to give strong support to the "free flow" theory, the doctrine of "prior consent" wins out for two reasons.

First, although a reading of the above-mentioned documents may leave some ambiguity with respect to whether "prior consent" or "free flow" is the governing law, this ambiguity is resolved when state practice is taken into account. ${ }^{11}$ The recognition of a

9 Universal Declaration of Human Rights, art. 19, U.N. G.A. Res. 217A(III), U.N. Doc. A/811 (1948) (emphasis added). See also Recommendation 2 of the International Telecommunications Union which recommends that "Members of the Union facilitate the unrestricted transmission of news by telecommunication services." Recommendation 2 of the International Telecommunications Union, Unrestricted Transmission of News and the Right to Communicate (1994), available at http://www.itu.int/aboutitu/basic-texts/recommen dations/recom02.html.

10 International Covenant on Civil and Political Rights, art. 19(2), G.A. Res. 2200A (XXI), 21 U.N. GAOR Supp. (No. 16) at 52, U.N. Doc. A/6316 (1966), 999 U.N.T.S. 171 (1976) [hereinafter, ICCPR].

11 Ambiguities are also present within the individual documents themselves. For example, the preamble to Resolution $37 / 92$ invokes "the 
customary international law requires evidence of the widespread and uniform practice of nations that engage in such practices out of a sense of legal obligation, or opinio iuris. ${ }^{12}$ Although treaties, resolutions, and declarations are good source of evidence regarding customary international law, state practice can provide equally valid evidence. ${ }^{13}$ And with respect to the issue of trans-border DBS broadcasting, state practice provides undeniable evidence that customary international law requires "prior consent." Virtually every country (and certainly all developed countries) regulate satellite transmissions into their country by way of rigorous licensing regimes. ${ }^{14}$ Even the United States, which has been the strongest proponent of the "free flow" doctrine, regulates satellite transmissions through a rigorous licensing process administered by the Federal

right of everyone to seek, receive and impart information and ideas" which appears to support the "free flow" doctrine, despite the fact that the resolution takes a "prior consent" approach in its Article 19. Resolution 37/92, supra note 1, preamble. For a discussion of internal ambiguities contained in the Mass Media Declaration see Paul, supra note 5, at 359.

12 See Jack L. Goldsmith \& Eric A. Posner, A Theory of Customary International Law, $66 \mathrm{U}$. CHI. L. REV. 1113, 1116 (1999) (with citations).

13 Evidence of customary international law can be found in treaties, international court decisions, domestic court decisions, domestic legislation, state action, and scholarship. See Mariana Mello, Hagan v. Australia: A Sign of the Emerging Notion of Hate Speech in Customary International Law, 28 LOY. L.A. INT'L \& COMP. L. REV. 365, 368 (2006).

14 See Paul, supra note 6, at 347 ("Even a cursory review of actual country practice ... would indicate that countries do not in fact recognize an asserted right to impart and receive information across national borders.")
Communications Commission. ${ }^{15}$ When divining a rule of customary international law, the opinio iuris of states carries great weight, and is most clearly expressed by a state's practices. The opinio iuris of the United States is undoubtedly that the "prior consent" doctrine governs DBS transmission. Otherwise, why would the United States adopt this approach in its domestic law in the form of license requirements? Once the weight of the United States is thrown behind the "prior consent" doctrine, there is little room left for arguing the "free flow" doctrine.

Second, application of the lex specialis rule of treaty interpretation demands that the more specific international law requiring "prior consent" for DBS television broadcasting trumps the more general rule permitting the "free flow" of information across borders. The lex specialis maxim states that "special provisions are ordinarily more effective than those that are general."16 Under the rule of lex specialis, since the "prior consent" doctrine is a more specific rule that applies exclusively to satellite broadcasting, it should override the

15 For a detailed discussion of United States opposition to the "prior consent" doctrine (in contrast to its state practice) see DAVID I. FISHER, PRIOR CONSENT TO INTERNATIONAL DIRECT SATELLITE BROADCASTING 139 (1990).

16 See, e.g., Robert Howse \& Petros C. Mavroidis, Europe's Evolving Regulatory Strategy for GMOS - The Issue of Consistency With WTO Law: Of Kine and Brine, 24 FORDHAM INT'L L.J. 317, 322 (2000) (quoting Grotius). Although the principle of lex specialis was not codified in the Vienna Convention on the Law of Treaties, it is widely recognized as a customary international law of treaty interpretation. See IAN SINCLAIR, THE VIENNA CONVENTION ON THE LAW OF TREATIES 96 (1984). 
general pronouncements regarding the more generalized right to the "free flow" of information.

For the foregoing reasons, international law is likely to require the consent of a receiving state before a sending state can transmit DBS television signals. Of course, under Article 28 of the Statute of the International Court of Justice, this customary international law, once established, binds all nations. ${ }^{17}$

\section{B. The Prohibition of War Propaganda}

In addition to the requirement of "prior consent," DBS broadcastings could, depending on the content of the transmission, violate the international law prohibiting certain types of propaganda.

There is no international agreement on a definition of propaganda. The most liberal approach defines propaganda as any "systematic attempt through mass communication to influence thinking and behavior."18 This definition of propaganda would capture even a fact-based news program, such as $\mathrm{CNN}$, provided that it was broadcasted with the intent "to influence thinking and behavior." A more restrictive approach, as adopted by reference in the preamble of the Outer Space Treaty, is found in

17 Statute of the International Court of Justice, art. 38, 59 Stat. 1055 (1945). See also, e.g., Jordan J. Paust, The Importance of Customary International Law During Armed Conflict, 12 ILSA J. INT'L \& COMP. L. 601, 602 (2006) (explaining that "when a customary norm comes into existence it is universally applicable.")

18 LESLIE JOHN MARTIN, INTERNATIONAL PROPAGANDA: ITS LEGAL AND DIPLOMATIC CONTROL 12 (1958); see also Stephen T. Bayer, The Legal Aspects of TV Marti in Relation to the Law of Direct Broadcasting Satellites, 41 EMORY L.J. 541, 550 (1992).
United Nations General Assembly Resolution 110 (II) which condemns "all forms of propaganda, in whatsoever country conducted, which is either designed or likely to provoke or encourage any threat to the peace, breach of the peace, or act of aggression."19

Only the latter, hostile type of propaganda is prohibited by international law. This prohibition arises under treaty law as well as international customary law. The 1936 League of Nations Convention Concerning the Use of Broadcasting in the Cause of Peace prohibits transmissions that "constitute an incitement either to war . . . or to acts likely to lead thereto."20 Likewise, Article 20 of ICCPR prohibits "any propaganda for war."21 Both documents contemplate the inflammatory propaganda that actively provokes war. The ICCPR, in particular, should be interpreted narrowly in light of its original purpose, namely, to prohibit the fascist war propaganda machine used by the Third Reich to promote German wars of aggression. ${ }^{22}$ In addition to these explicit treaty prohibitions, it is widely recognized that customary international

\footnotetext{
19 United Nations General Assembly Resolution 110(11)), 1947-48 U.N.Y.B. 93 (1947). The U.N. Committee on the Peaceful Uses of Outer Space (UNCOPUOS) has also defined propaganda as a hostile act intended to provoke war, incite sedition, interfere with the receiving state's internal affairs, slander the receiving state, or violate human rights. See U.N. GAOR Committee on the Peaceful Uses of Outer Space, 25th Sess., at 7, U.N. Doc. A/ AC.105/79 (1970).

20 International Convention Concerning the Use of Broadcasting in the Cause of Peace, art. 2, Sept. 23, 1936, 186 L.N.T.S. 301

${ }^{21}$ ICCPR, supra note 10 , art. 20.

22 See CENTRAL EUROPEAN AND EURASIAN LAW INITIATIVE, ICCPR LEGAL IMPLEMENTATION INDEX 140 (2003)
} 
law prohibits war propaganda as well. ${ }^{23}$ It can certainly be said that no country objects to such a prohibition. ${ }^{24}$

Since news programs such as CNN do not actively incite war, the DBS transmission of commercial news programs should not be affected by the prohibition against war propaganda.

\section{The "Peaceful Purposes" Doctrine}

Direct satellite broadcasts in time of war may also be affected by the restrictions on the military use of space contained in the Treaty on Principles Governing the Activities of States in the Exploration and Use of Outer Space, Including the Moon and Other Celestial Bodies (Outer Space Treaty) - which is often referred to as the Magna Carta of space law. ${ }^{25}$ There are two ways to interpret the Outer Space Treaty with respect to the militarization of Earth orbits. One possible interpretation is that the military use of earth's orbit is permitted - with the sole limitation that no nation may place into orbit "any objects carrying nuclear weapons or any other kinds of weapons of mass destruction."26 This interpretation is founded on a plain language reading of Article IV of the Outer Space Treaty

\footnotetext{
23 See Elizabeth A. Downey, A Historical Survey of the International Regulation of Propaganda, in MICHIGAN YEARBOOK OF INTERNATIONAL LEGAL STUDIES: REGULATION OF TRANSNATIONAL COMMUNICATIONS 341 (1984); see also Bayer, supra note 18 , at 549 .

24 Id.

25 Treaty on Principles Governing the Activities of States in the Exploration and Use of Outer Space, including the Moon and Other Celestial Bodies, 18 U.S.T. 2410, 610 U.N.T.S. 205 (entered into force Oct. 10, 1967) [hereinafter, Outer Space Treaty].

${ }^{26}$ Id. art. IV.
}

which states that " $[t]$ he Moon and other celestial bodies shall be used by all States Parties to the Treaty exclusively for peaceful purposes." 27 A plain reading of this provision suggests that the "peaceful purpose" requirement applies only to use of the Moon and celestial bodies - but does not apply to other regions of outer space, thus allowing for the militarization of the Earth orbits (with the exception of on-orbit weapons of mass destruction). ${ }^{28}$

An alternative interpretation of the Outer Space Treaty relies on a more expansive reading of the treaty and holds that the "peaceful purpose" doctrine applies to all of outer space, including Earth orbits. This interpretation relies both on customary international law as reflected in the practice of states (which is incorporated into the Outer Space Treaty via Article III which states that the use of outer space shall be carried out "in accordance with international law") and on the language of the preamble to the Outer Space Treaty which emphasizes the "use of outer space for peaceful purposes" in two places. ${ }^{29}$ Commentators generally agree that customary international law requires that all of outer space, including earth orbits, be used only for "peaceful purposes."30

\footnotetext{
${ }^{27} \mathrm{Id}$.

28 See GENNADY ZHUKOV \& YURI KOLOSOV, INTERNATIONAL SPACE LAW 53 (1984) (arguing that the Outer Space Treaty requires "total neutralization and demilitarization of celestial bodies and [only] partial demilitarization of outer space"); Michel Bourbonniere, National-Security Law in Outer Space: The Interface of Exploration and Security, 70 J. AIR L. \& COM. 3, 16 (2005)

${ }^{29}$ Outer Space Treaty, supra note 25, preamble.

30 See, e.g., Bourbonniere, supra note 28, at 16; Richard A. Morgan, Military Use of Commercial Communication Satellites: A New Look at the
} 
How does this "peaceful purposes" requirement affect the use of communications satellites in time of war? Before we answer this, further analysis should be given to the meaning of the phrase "peaceful purposes." There are three basic approaches to the interpretation of the "peaceful purposes" doctrine. Under the first approach, some commentators argue for the absolute demilitarization of outer space. ${ }^{31}$ Pursuant to the second approach, the word "peaceful" is treated as equivalent to "non-aggressive," thus allowing the military to use communications satellites for non-tactical support of military operations, such as for communications, navigation, and weather monitoring. ${ }^{32}$ The third approach also adopts the "nonaggressive" definition of "peaceful," but applies a broader interpretation which allows for the use of space assets, including satellites, for any action taken

Outer Space Treaty and "Peaceful Purposes", 60 J. AIR L. \& COM. 237, 242 (1994) (explaining that "[s]upport for the conclusion that current international law requires all of outer space to be used for "peaceful purposes" is compelling.").

31 See, e.g., Ricky Lee, Reconciling International Space Law with the Commercial Realities of the Twenty-First Century, 4 SING. J. INT'L \& COMP. L. 194, 214 (2000) ("[T]he United States would . . not to undertake a new obligation involving the full demilitarisation of space. This interpretation is contrary to existing interpretations that are found in international law.")

32 See, e.g., Robert L. Bridge, International Law and Military Activities In Outer Space, 13 AKRON L. REV. 649, 658 (1979). This interpretation of the "peaceful purposes" doctrine relies heavily on the language of the UN Charter which states as its overarching goal "international peace and security," but at the time allows for military action to "suppress acts of aggression." Charter of the United Nations, art. 1, 59 Stat. 1031, T.S. No. 993 (1945) [hereinafter, UN Charter]. in accordance with the UN Charter, thus allowing full military use of space for purpose of self-defense or as ordered by the UN Security Council. ${ }^{33}$

Only under the first approach to the "peaceful purposes" doctrine might a state's DBS broadcasting of commercial news be restricted since this strict interpretation may be taken so far as to prohibit any use of space assets by the military, even if such use occurs in peacetime and is not related to a military strike. ${ }^{34}$ However, this would require the broadcast to be characterized as a military operation, which may not be easily determined. Moreover, since this strict interpretation requiring the total demilitarization of space does not find wide support, it is unlikely to create a bar to DBS broadcasting of a news program. Under the second approach, the use of satellites to broadcast news, even if part of a broader campaign to achieve a military victory, is likely to be deemed permissible since it is more akin to a non-tactical support activity in light of the fact that it bears no relation to a military strike. Finally, under the third approach DBS news broadcasts would be permissible even if deemed to be part of a tactical military operation, provided that the broadcast was part of a military

33 This third approach reflects the principle stated in Resolution 3314 of the UN General Assembly which provides that "[a]ggression is the use of armed force by a State against the sovereignty, territorial integrity or political independence of another State, or in any other manner inconsistent with the Charter of the United Nations." United Nations General Assembly Resolution 3314 (XXIX): Definition of Aggression, art. I, G.A. Res. 3314, U.N. GAOR, 29th Sess., Supp. No. 31, U.N. Doc. A/9631 (Dec. 14, 1974). For a recent detailed discussion of various approaches to the "peaceful purposes" doctrine see Morgan, supra note 30.

${ }^{34}$ See, e.g., Lee, supra note 31 , at 215. 
campaign that was justified under the UN Charter.

D. Preliminary Conclusion: The "Prior Consent" Doctrine is the Only Restriction on the DBS Broadcasting of Commercial News Programs

In light of the foregoing, the DBS transmission of news programs should not be banned by either the prohibition against war propaganda or the "peaceful purposes" doctrine. Therefore, the "prior consent" doctrine is the only restriction on broadcasting commercial news programs, such as $\mathrm{CNN}$, into an enemy state in time of war. This brings us to the final question addressed in this paper, namely, whether the right to self-defense can excuse a state from having to comply with the "prior consent" requirement in times of war.

\section{III. "PRIOR CONSENT" IN TIMES OF WAR}

Having established that the "prior consent" requirement applies to DBS satellite broadcasts of commercial news under our hypothetical scenario, the final question now presents itself: can a state invoke the right of self-defense as a basis for refusing to comply with the "prior consent" doctrine in times of war? ${ }^{35}$

The right of a state to act in selfdefense is based on customary international law and is recognized in Article 51 of the UN Charter which

35 It is assumed for purposes of the present discussion that the international law prohibiting broadcast without prior consent would continue in times of war. For further discussion regarding this issue see LaToya Tate, The Status of the Outer Space Treaty at International Law During "War" and "Those Measures Short of War", $32 \mathrm{~J}$. SPACE L. 177 (2006) states that "[n]othing in the present Charter shall impair the inherent right of individual or collective self-defence if an armed attack occurs."36 Under customary international law, the right of self-defense permits a state to respond to an armed attack with "measures which are proportional to the armed attack and necessary to respond to it." 37 Therefore, a state would only be able to bypass the "prior consent" requirement if broadcasting into the enemy state was "necessary" for its defense. It is unlikely that a state could successfully make this argument in the context of the classical theory of self-defense which assumes that actions taken in self-defense are necessary in order to respond to an immediate threat. The broadcasting of a news program would not provide much protection against an immediate military threat. However, some nations have adopted a more liberal view which allows for anticipatory self-defense in the face of an imminent threat. ${ }^{38}$ Moreover, in response to the growing threat of terrorism, the United States has further relaxed its understanding of the doctrine of self-defense to allow for military action to guard against a "continuing threat" even when no strike is known to be imminent. ${ }^{39}$ It is under this "continuing threat" theory of selfdefense that the "prior consent" requirement could, arguably, be set aside if DBS broadcasting of commercial news programs were deemed to be a necessary measure for the nullification

\footnotetext{
36 UN Charter, supra note 32, art. 51.

37 Nicaragua v. United States of America, 1986 I.C.J. 14 (emphasis added).

38 See, e.g., Howard A. Wachtel, Targeting Osama Bin Laden: Examining the Legality of Assassination as a Tool of U.S. Foreign Policy, 55 DUKE L.J. 677, 691-92 (2005).

${ }^{39}$ Id.
} 
of a continuing terrorist threat. This argument of necessity could conceivably be based on the idea that force alone cannot defeat terrorism, but must be coupled with the free flow of information that can counteract misinformation and dispel the cultural misunderstandings that foster extremism.

\section{THE RIGHT TO JAM ILLEGAL SATELLITE TRANSMISSIONS}

The question regarding the right of a state to broadcast satellite television is only part of a greater debate. The complementary issue is whether, and to what extent, a state has the right to jam satellite television transmissions.

As was true regarding the right to broadcast, there are two main schools of thought regarding jamming. Some argue that jamming violates the fundamental right of people to impart and receive information under Article 19 of the Universal Declaration of Human Rights and Article 19 of the ICCPR, both of which provide that all people have a fundamental right "to seek, receive, and impart information and ideas." 40 Others have argued that the right to jam unwanted signals goes hand-in-hand with a state's right to regulate the flow of telecommunications into its territory. It is argued that this right to use jamming technology is a necessary tool to assert state sovereignty and is complementary to the doctrine of "prior consent." Just as a state should not be subjected to media transmissions without its consent, so should a state have a right to jam a signal for which it has not given the required consent.

In support of the legality of jamming, proponents have argued that

\footnotetext{
40 Universal Declaration of Human Rights, supra
} note 9, art. 19; ICCPR, supra note 10, art. 19. the general proclamations of the right to exchange information are trumped, under the rule of lex specialis, by more specific expressions of international law which have permitted states to maintain sovereign control over media transmissions. Such commentators have looked primarily to Article 19(2) of the International Telecommunications Convention (ITC) which allowed states to stop transmissions that endanger the "security of the State or are contrary to their laws, to public order or to decency."41 Similarly, Article 20 of the ITC provided that a state may suspend "international telecommunications service" for an indefinite time (provided that the Secretary-General is notified). ${ }^{42}$ However, the ITC has since been supplanted by the Constitution of the International Telecommunications Union (the "ITU Constitution") and the Convention of the International Telecommunications Union, which can be said to take a more liberal approach to the "free flow" of information. 43

Even without a strong argument on the basis of lex specialis, state practice supports a customary international law allowing the jamming of unwanted signals. Although the majority of examples of state practice of signal jamming involve totalitarian states such as Soviet Russia, Cuba, Libya and Iran, there are also examples of western democracies engaging in jamming, at

\footnotetext{
41 International Telecommunications Convention, art. 19(2), 32 U.S.T. 3821 [hereinafter ITC].

42 Id. art. 20.

43 Constitution of the International Telecommunications Union, available at http://www.itu.int/aboutitu/basic-texts/ constitution.html [hereinafter ITU Constitution]; Convention of the International Telecommunication Union, available at http:// www.ito.int/aboutitu/basic-texts/convention.html [hereinafter ITU Convention].
} 
least in times of war. ${ }^{44}$ Moreover, the practices of western states once again confirm that jamming is permissible as a customary international law in light of the pervasive licensing regimes that western countries administer. Unlicensed satellite broadcasts are not tolerated in any industrialized country. Therefore, it would be difficult to make the argument that such states do not support, at least to some extent, the principle that states have sovereign control over their media transmission in their territory. ${ }^{45}$

Pursuant to the foregoing, states likely have the right under international law to jam illegal transmissions. This

${ }^{44}$ See David Hencke \& Owen Gibson, Protest to Libya after Satellites Jammed, THE GUARDIAN, Dec. 3, 2005, available at http://www.guardian.co.uk/libya/story/0,,165691 4,00 html (regarding Libya's jamming of two commercial satellites); Tom Carter, Castro Regime Jamming U.S. Broadcasts into Iran, THE WASHINGTON TIMES, July 16, 2003, available at http://www.washingtontimes.com/functions/ print.php?StoryID=20030715-114937-2635r

(regarding Cuba's jamming of Telstar-12 transmission of Voice of America broadcasts in Farsi into Iran); Bayer, supra note 18, at 572 (describing how Cuba jammed TV Marti broadcasted from an aerostat - within minutes of its launch in 1990); see also Adeno Addis, The Thin State in Thick Globalism: Sovereignty in the Information Age, 37 VAND. J. TRANSNAT'L L. 1, 30 (2004). The significance of jamming by Cuba and other countries with respect sto the formation of customary international law may be weakened if it is shown that such practices are conducted in secret, which would indicate that such practices do not reflect the country's opinio iuris.

45 For further discussion regarding territorial sovereignty and media broadcasts see OPPENHEIM'S INTERNATIONAL LAW 529 (1955). One question that presents itself here is whether an intermediate rule of customary international law can be formulated which only permits regulation of media transmissions in accordance with reasonable rules that are politically neutral. right applies to the jamming of war propaganda without question, but it is also likely to apply to the jamming of any transmission made without the receiving state's consent. However, there are certainly limits to what form the jamming can take. If the purpose of the jamming is merely to enforce the doctrine of "prior consent" or block the transmission of war propaganda, then the jamming should be limited to what is necessary to jam the objectionable signals. Causing greater interference than necessary would likely violate Article 45 of the ITU Constitution which prohibits states from causing "harmful interference" to the telecommunications of other states. ${ }^{46}$ Similarly, the jamming would likely be subject to the proportionality requirement applicable to actions taken in self-defense (although application of the proportionality requirement in the absence of an armed or imminent attack is uncertain). Therefore, the jamming should be of no greater magnitude than necessary to obstruct the illegal transmission. Disproportional jamming can cause harm to innocent third parties who use neighboring transponders, as was the case when U.S. commercial radio broadcasters suffered revenue loss due to interference caused by Cuban jamming of Radio Marti. ${ }^{47}$

\section{CONCLUSION}

Both treaty law and customary international law require that a sending

\footnotetext{
46 ITU Constitution, supra note 43 , art. 45.

47 See Bayer, supra note 18 , at 570-71 \& n. 191. The commercial broadcasters were compensated by the U.S. government pursuant to the Radio Broadcast to Cuba Act. See Compensation of Expenses to Mitigate Cuban AM Interference Cuban Interference, 97 F.C.C.2d 181 (1984).
} 
state acquire the consent of a receiving state before using DBS broadcasting to transmit television programs, such as commercial news programs. The "prior consent" requirement is the only restriction under international law that is applicable to the broadcasting of such news programs since the programs do not rise to the level of illegal war propaganda nor would such broadcasts be prohibited by the international law demanding that outer space be used only for "peaceful purposes." Not restricted to peacetime, this requirement of "prior consent" continues in times of war. The only law of war that could threaten the integrity of the "prior consent" doctrine is a state's fundamental right to selfdefense. However, it is unlikely that the right to self-defense could be invoked as an excuse for failing to comply with the "prior consent" requirement since the broadcasting of news media could never be necessary for self-defense against an immediate threat. However, the inviolability of the "prior consent" doctrine may be threatened by the recent adoption by the United States of a more relaxed theory of self-defense.

Finally, in the event that a state does broadcast into another state without first securing prior consent, the receiving state has the right to jam such broadcasts, with the sole proviso that any such jamming must be proportional so as to minimize unnecessary interference that might cause harm to innocent parties.

\section{$\underline{\text { References Cited }}$}

1. Joel R. Paul, Images from Abroad: Making Direct Broadcasting by Satellites Safe for Sovereignty, 9 HASTINGS INT'L \& COMP. L. R. 329 (1986)
2. Jack L. Goldsmith \& Eric A. Posner, A Theory of Customary International Law, $66 \mathrm{U}$. CHI. L. REV. 1113 (1999)

3. Mariana Mello, Hagan v. Australia: A Sign of the Emerging Notion of Hate Speech in Customary International Law, 28 LOY. L.A. INT'L \& COMP. L. REV. 365 (2006)

\section{DAVID I. FISHER, PRIOR CONSENT TO INTERNATIONAL DIRECT SATELLITE BROADCASTING (1990)}

5. Robert Howse \& Petros C. Mavroidis, Europe's Evolving Regulatory Strategy for GMOS - The Issue of Consistency With WTO Law: Of Kine and Brine, 24 FORDHAM INT'L L.J. 317 (2000)

6. IAN SINCLAIR, THE VIENNA CONVENTION ON THE LAW OF TREATIES (1984)

7. Jordan J. Paust, The Importance of Customary International Law During Armed Conflict, 12 ILSA J. INT'L \& COMP. L. 601 (2006)

8. LESLIE JOHN MARTIN, INTERNATIONAL PROPAGANDA: ITS LEGAL AND DIPLOMATIC CONTROL (1958)

9. Stephen T. Bayer, The Legal Aspects of TV Marti in Relation to the Law of Direct Broadcasting Satellites, 41 EMORY L.J. 541 (1992)

10. Elizabeth A. Downey, A Historical Survey of the International Regulation of Propaganda, in MICHIGAN YEARBOOK OF INTERNATIONAL LEGAL STUDIES: REGULATION OF TRANSNATIONAL COMMUNICATIONS (1984)

11. GENNADY ZHUKOV \& YURI KOLOSOV, INTERNATIONAL SPACE LAW (1984)

12. Michel Bourbonniere, National-Security Law in Outer Space: The Interface of Exploration and Security, 70 J. AIR L. \& COM. 3 (2005)

13. Richard A. Morgan, Military Use of Commercial Communication Satellites: A New Look at the Outer Space Treaty and "Peaceful Purposes", 60 J. AIR L. \& COM. 237 (1994) 
14. Ricky Lee, Reconciling International Space Law with the Commercial Realities of the Twenty-First Century, 4 SING. J. INT'L \& COMP. L. 194 (2000)

15. Robert L. Bridge, International Law and Military Activities In Outer Space, 13 AKRON L. REV. 649 (1979)

16. LaToya Tate, The Status of the Outer Space Treaty at International Law During "War" and "Those Measures Short of War", 32 J. SPACE L. 177 (2006)

17. Howard A. Wachtel, Targeting Osama Bin Laden: Examining the Legality of Assassination as a Tool of U.S. Foreign Policy, 55 DUKE L.J. 677 (2005)

18. Adeno Addis, The Thin State in Thick Globalism: Sovereignty in the Information Age, 37 VAND. J. TRANSNAT'L L. 1 (2004)

19. OPPENHEIM'S INTERNATIONAL LAW (1955). 


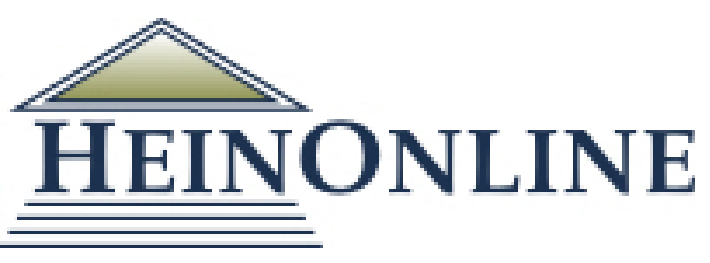

Content downloaded/printed from

HeinOnline

Thu Dec 12 08:09:26 2019

Citations:

Bluebook 20th ed.

MarkJ. Sundahl, Information Warefare: The Legal Aspects of Using Satellites and Jamming Technologies in Propaganda Battles, 49 Proc. on L. Outer Space 354 (2006).

ALWD 6th ed.

MarkJ. Sundahl, Information Warefare: The Legal Aspects of Using Satellites and Jamming Technologies in Propaganda Battles, 49 Proc. on L. Outer Space 354 (2006).

APA 6th ed.

Sundahl, M. (2006). Information Warefare: The Legal Aspects of Using Satellites and Jamming Technologies in Propaganda Battles. Proceedings on the Law of Outer Space, 49, 354-365.

Chicago 7th ed.

MarkJ. Sundahl, "Information Warefare: The Legal Aspects of Using Satellites and Jamming Technologies in Propaganda Battles," Proceedings on the Law of Outer Space 49 (2006): 354-365

McGill Guide 9th ed.

MarkJ Sundahl, "Information Warefare: The Legal Aspects of Using Satellites and Jamming Technologies in Propaganda Battles" (2006) 49 Proceedings on the $L$ of Outer Space 354.

MLA 8th ed.

Sundahl, MarkJ. "Information Warefare: The Legal Aspects of Using Satellites and Jamming Technologies in Propaganda Battles." Proceedings on the Law of Outer Space, 49, 2006, p. 354-365. HeinOnline.

OSCOLA 4th ed.

MarkJ Sundahl, 'Information Warefare: The Legal Aspects of Using Satellites and Jamming Technologies in Propaganda Battles' (2006) 49 Proc on L Outer Space 354

Provided by:

Cleveland-Marshall College of Law Library

-- Your use of this HeinOnline PDF indicates your acceptance of HeinOnline's Terms and Conditions of the license agreement available at https://heinonline.org/HOL/License

-- The search text of this PDF is generated from uncorrected OCR text.

Use QR Code reader to send PDF to your smartphone or tablet device 